\title{
KEWAJIBAN UNTUK MENJAGA KERAHASIAAN AKTA \\ OLEH NOTARIS DAN KARYAWAN NOTARIS DALAM PERSPEKTIF HUKUM
}

\author{
Rahmida Erliyani \\ Faculty of Law, Lambung Mangkurat of University \\ E-mail:rahmidaerliyani@ulm.ac.id \\ Muhammad Hadin Muhjad \\ Faculty of Law, Lambung Mangkurat of University \\ E-mail: hadinmuhjad@gmail.com \\ Lia Audia Puspita \\ Master Of Notary, Faculty of Law, Lambung Mangkurat University \\ E-mail: lyafortuna1@icloud.com
}

\begin{abstract}
Abstrak
Tujuan dari penelitian ini adalah untuk mengetahui dan memahami Esensi dan Kesaksian Saksi dalam UU Notaris. Serta mengetahui dan memahami akibat hukum bagi mantan pegawai Notaris yang memberikan informasi untuk membuka kerahasiaan akta tersebut. Kegunaan penelitian ini adalah sebagai bahan informasi dalam rangka pengembangan ilmu dan wawasan dalam disiplin ilmu hukum khususnya hukum notaris. Dan sebagai sumbangan pemikiran dalam memperkaya cakrawala bagi pihak-pihak terkait. Menurut hasil penelitian, kedudukan saksi dalam hukum notaris adalah memenuhi syarat formal suatu akta. Kedudukan saksi merupakan satu kesatuan dalam akta notaris, saksi yang berasal dari pegawai Notaris dalam praktek dilapangan tidak selalu merupakan pegawai yang mengetikkan perbuatan para pihak. Tidak jarang karyawan yang menjadi saksi penandatanganan dan pembacaan akta tersebut hanya mengetahui pada saat kejadian berlangsung. Jadi pegawai Notaris dalam kedudukannya sebagai saksi tidak wajib mengingat isi akta tersebut. Selama tidak melakukan perbuatan melawan hukum dalam menjalankan tugasnya sebagai pegawai Notaris untuk mengetikkan akta para pihak, keberadaannya dalam akta notaris tidak bertentangan dengan ketentuan wajib Notaris untuk menjaga isi akta tersebut. kewajiban untuk mendapatkan akta notaris dan pegawai notaris?
\end{abstract}

Kata-Kunci: Karyawan Notaris; Saksi; Kerahasian Akta 


\section{Abstract}

The purpose of this study is to find out and understand the Witnesses' Essence and Testimony in notary law. And to know and understand the legal consequences for former Notary employees who provide information to open the confidentiality of the deed. The usefulness of this research is as information material within the framework of the development of science and insights in legal disciplines, especially notary law. And as a contribution of thought in enriching the horizons for the parties concerned. According to the results of the study that the position of witnesses in notary law is to meet the formal requirements of a deed. The position of a witness is a unity in a notarial deed, witnesses who come from Notary employees in practice in the field are not always employees who type the deeds of the parties. It is not uncommon for employees who are witnesses to the signing and reading of the deed to know only at the time the incident took place. So the Notary employee in his position as a witness is not obliged to remember the contents of the deed. As long as he does not commit illegal acts in his duties as a Notary employee to type the deeds of the parties, his existence in a notarial deed does not conflict with the provisions of the Notary compulsory to keep the contents of the deed.And how the obligation to be awarded the deed by o notary and notary employee?

Keywords: Notary Employee; Witness; Confidentaility of Deed

\section{PENDAHULUAN}

Di Indonesia ada 3 (tiga) jabatan yang dikualifikasikan sebagai Pejabat Umum, yaitu Notaris, PPAT, dan Pejabat Lelang. Ketiga jabatan tersebut mempunyai kewenangan masing-masing sesuai dengan aturan peraturan perundang-undangan yang mengatur jabatan tersebut. Semua produk (akta ataupun lainnya) atau tindakan hukum lainnya akan dapat dipertanggung jawabkan secara hukum jika dilakukan sesuai dengan kewenangannya.

Akta yang dibuat Notaris tanpa ada kewenangannya maka dapat disimpulkan bahwa akta yang bersangkutan batal demi hukum, dan semua perbuatan atau tindakan hukum yang tersebut dalam akta harus dianggap tidak pernah terjadi. Dan akta seperti ini tidak dapat dieksekusi. Untuk Notaris yang membuat aktanya dapat dituntut pergantian biaya, ganti rugi, dan bunga dengan alasan ketidaktahuan Notaris akan ketidakwenangannya tidak untuk membuat akta yang bukan menjadi kewenangannya. ${ }^{1}$

${ }^{1}$ Habib Adjie, Penafsiran Tematik Hukum Notaris Indonesia. (Surabaya : Refika Aditama, 2017), hlm 14. 
Notaris adalah pejabat umum yang satu-satunya berwenang untuk membuat akta otentik mengenai semua perbuatan, perjanjian dan penetapan yangn diharuskan oleh suatu peraturan umum atau oleh yang berkepentingan dikehendaki untuk dinyatakan dalam suatu akta otentik, menjamin kepastian tanggalnya, menyimpan aktanya dan memberikan grosse, salinan dan kutipannya semua sepanjang pembuatan akta itu oleh suatu peraturan umum tidak juga ditugaskan atau dikecualikan kepada pejabat atau orang lain. ${ }^{2}$

Notaris dikonstruksikan sebagai pejabat-pejabat umum. Pejabat umum merupakan orang yang melakukan pekerjaan atau tugas untuk melayani kepentingan masyarakat secara keseluruhan. ${ }^{3}$ Jabatan yang dimiliki oleh Notaris merupakan jabatan kepercayaan dimana seseorang bersedia mempercayakan sesuatu kepadanya sehingga selayaknyalah sebagai orang kepercayaan, Notaris memiliki kewajiban untuk merahasiakan semua yang diberitahukan kepadanya selaku Notaris, sekalipun ada sebagian yang tidak dicantumkan dalam akta. Pasal 4 dan Pasal 16 ayat (1) huruf $\mathrm{f}$ Undang-Undang Jabatan Notaris mewajibkan Notaris untuk menjaga kerahasiaan segala sesuatu mengenai akta yang dibuatnya dan segala keterangan yang diperoleh guna pembuatan akta sesuai dengan sumpah janji jabatan kecuali undang-undang menentukan lain.

Adanya kewajiban bagi Notaris untuk merahasiakan isi akta dan segala keterangan yang diperoleh dalam pembuatan akta ini bertujuan untuk melindungi kepentingan para pihak yang terkait dengan akta tersebut. Jika ternyata Notaris yang dipanggil dalam pemeriksaan membuka rahasia dan memberikan keterangan yang seharusnya dirahasiakan, maka pihak yang merasa dirugikan dapat mengadukan Notaris kepada pihak yang berwajib. ${ }^{4}$ Salah satu syarat formal yang harus ada dalam akta Notaris adalah hadirnya 2 (dua) orang saksi yang identitasnya disebutkan secara tegas pada akhir akta. Hal ini secara tegas dicantumkan dalam Pasal 40 ayat (1) UUJN yang berbunyi "Setiap Akta yang dibacakan oleh Notaris dihadiri paling sedikit 2 (dua) orang saksi, kecuali peraturan perundang-undangan menentukan lain". Dalam ruang lingkup kenotariatan dikenal dua macam saksi, yaitu saksi kenal dan saksi instrumentair. ${ }^{5}$ Saksi akta Notaris merupakan para saksi yang ikut serta di dalam pembuatan terjadinya akta (instrument), maka dari itulah disebut saksi instrumentair (instrumentaire getuigen).

${ }^{2}$ Lumbang Tobing, Peraturan Jabatan Notaris, (Jakarta : Erlangga, 2002), hlm. 3.

${ }^{3}$ Salim HS, Peraturan Jabatan Notaris, (Jakarta : Sinar Grafika, 2018), hlm. 6.

${ }^{4}$ Komar Sugondo, Notaris Selayang Pandang, (Bandung : Cetakan Kedua Alumni, 2000), hlm. 13 .

5 Ibid, hlm. 268. 
Dalam kaitannya bahwa Notaris dipercaya oleh para pihak mampu merahasiakan dan menyimpan semua keterangan atau pernyataan para pihak yang pernah diberikan dihadapan Notaris yang berkaitan dengan pembuatan akta. Menurut ketentuan ini maka seorang Notaris haruslah merahasiakan segala sesuatunya mengenai akta yang dibuatnya dan segala keterangan yang diperoleh guna pembuatan akta sesuai dengan sumpah atau janji jabatan. Namun dalam pembuatan suatu akta juga akan melibatkan pihak lain sebagai saksi suatu akta atau dikenal dengan istilah saksi instruumentair. Umumnya karyawan di kantor notaris itu yang dijadikan saksi akta,sehingga dalam hal ni juga menarik untuk dianalisa bagaimana pula kewajiban merahasiakan akta sebagaimana dimanatkan oleh Undang Undanng Jabatan Notaris,apakah juga berlaku untuk karyawan notaris ? Oleh karena itulah maka penulis berkmaksud menganalisis mengenai kewajiban merahasiakan akta oleh notaris dan karyawan nya ini dalam suatu kajian ilmiah dengan merumuskan permasalahan yang akan di analisis yakni sbb :

1. Bagaimana hakikat saksi untuk suatu akta?

2. Bagaimana kewajiban Notaris dan karyawan Notaris dalam menjaga kerahasiaan akta?

\section{METODE PENELITIAN}

Dalam hal ini penulis menggunakan jenis penelitian hukum normatif, penelitian hukum normative adalah penelitian yang mengkaji persoalan hukum dari sudut pandang ilmu hukum secara mendalam terhadap norma hukum yang dibentuk. ${ }^{6}$ Penelitian hukum ini dilakukan dengan menganalisa suatu permasalahan melalui peraturan perundang-undangan, literaturliteratur, dan bahan-bahan referensi lainnya.

Pendekatan yang digunakan dalam penelitian ini adalah Pendekatan Peraturan Perundang-Undangan (Statue Approach), dan Pendekatan Konsep (Conceptual Approach).

Adapun tipe penelitian hukum ini adalah tipe doctrinal reseach, yang meliputi issu hukum berupa kurang lengkapnya pengaturan hukum dalam Undang Undang Jabatan Notaris berkenaan tentang kewajiban merahsiakan akta oleh karyawan notaris yang menjadi saksi instrumentair dalam suatu akta.Kekaburan pengaturan hukum mengenai kewajiban merahasikan isi akta dalam pengaturannya pada Undang Undang Jabatan Notaris hanya mengatur dan memberikan kewajiban pada notaris sebagai pejabat pembuat akta.Sedangkan mengenai kewajiban bagi karyawan kantor

${ }^{6}$ Hadin Muhjad and Nunuk Nuswardani, Penelitian Hukum Indonesia Kontemporer, (Yogyakarta: Genta Publishing, 2012), hlm. 9. 
notaris yang menjadi saksi dalam suatu akta, tidak diatur dengan jelas mengenai kewajibannya dalam kerahasiaan akta.

Sifat penelitian ini berifat preskriptif, yakni berupaya berpikir dan berpandangan ke masa yang akan datang dalam menganalisi permasalahan ini,agar kekuranglengkapan atau kekaburan pengaturan hukum ini dapat teratasi dengan baik.

\section{PEMBAHASAN}

\section{Hakekat saksi pada suatu akta notaris}

KUHPerdata pada buku keempat bab ketiga tentang pembuktian dan saksi dalam Pasal 1895 KUHPerdata, Pasal 1902 KUHPerdata. Kemudian pengaturan tentang saksi juga terdapat di dalam KUHAP, diantaranya Pasal 1 angka 26, Pasal 159 sampai dengan Pasal 185 KUHAP. Menurut ketentuan yang diatur dalam Pasal 1 angka 26 KUHAP menyatakan bahwa "saksi adalah orang yang dapat memberikan keterangan guna kepentingan penyidikan, penuntutan dan peradilan tentang suatu perkara pidana yang ia dengar sendiri dan ia alami sendiri. Saksi juga merupakan alat bukti yang sah." Demikian pula tentang saksi diatur juga didalam Pasal 40 UUJN Perubahan dan di dalam Pasal 20 sampai 24 Peraturan Jabatan Notaris.

Pada ranah hukum kenotariatan, dalam peresmian suatu akta Notaris, dikenal 2 (dua) saksi, yaitu saksi kenal (saksi testamenter) dan saksi instrumentair. Saksi instrumentair adalah saksi yang harus hadir dalam pembuatan suatu akta, dalam arti pembacaan dan penandatanganan suatu akta. Sedangkan saksi kenal atau saksi attesterend adalah saksi yang memperkenalkan penghadap kepada Notaris karena penghadap tersebut tidak mempunyai identitas atau identitasnya diragukan oleh Notaris, kehadiran saksi adalah merupakan salah satu syarat sahnya suatu akta. Saksi yang menghadiri, menyaksikan dan menandatangani akta adalah saksi instrumentair. $^{7}$

Para saksi instrumentair tidak bertanggungjawab terhadap isi akta itu. Oleh Undang-undang tidak diwajibkan secara tegas kepada para saksi untuk merahasiakan isi akta tersebut, sehinngga terhadap saksi instrumentair ini tidak dapat diberlakkan ketentuan dalam pasal 322 KUHPidana. Saksi instrumentair dalam kedudukannya sebagai saksi tidak menjabat suatu jabatan atau pekerjaan sebagai yang dimaksud dalam pasal tersebut. Oleh karena itu apabila saksi instrumentair membocorkan isi dari suatu akta,

7 Tan Thong Kie, Studi Notariat Dan Serba Serbi Praktek Notaris, (Jakarta : Ichtiar Baru Van Hoeve, 2000), hlm. 647 
maka perbuatan tersebut merupakan suatu perbuatan melawan hukum sebagaiman yang dimkasud dalam pasal 1365 KUHPerdata. ${ }^{8}$

Di dalam Pasal 40 UUJN Perubahan tersebut telah jelas diatur mengenai saksi dalam peresmian dan pembuatan akta notaris yang berupa persyaratan bagi para saksi. Adapun ketentuan yang diatur dalam Pasal 40 UUJN Perubahan, untuk menjadi saksi diantaranya sebagai berikut :

1. Setiap akta yang dibacakan oleh Notaris dihadiri paling sedikit 2 (dua) orang saksi, kecuali peraturan perundangundangan menentukan lain;

2. Saksi sebagaimana dimaksud pada ayat (1) harus memenuhi syarat sebagai berikut :

a. Paling rendah berumur 18 (delapan belas) tahun atau sebelumnya telah menikah;

b. Cakap melakukan perbuatan hukum;

c. Mengerti bahasa yang digunakan didalam akta;

d. Dapat membubuhkan tanda tangan dan paraf;

e. Tidak mempunyai hubungan perkawinan atau hubungan darah dalam garis lurus keatas atau kebawah tanpa pembatasan derajat dan garis kesamping sampai dengan derajat ketiga dengan Notaris atau para pihak.

3. Saksi sebagaimana dimaksud pada ayat (1) harus dikenal oleh Notaris atau diperkenalkan kepada Notaris atau diterangkan tentang identitas dan kewenangannya kepada Notaris oleh penghadap;

4. Pengenalan atau pernyataan tentang identitas dan kewenangan saksi dinyatakan secara tegas dalam akta.

Kedudukan saksi akta Notaris tentunya berbeda dengan keduduakn saksi pada umumnya yang merupakan saksi yang mendengar dan atau melihat sendiri suatu peristiwa yang terjadi. Contohnya dalam suatu peristiwa jual beli, saksi umumnya adalah yang melihat terjadinya penyerahan uang dari pembeli dan penyerahan barang dari penjual. Tetapi pada saksi akta, bisa saja pembeli telah melakukan penyerahan uang secara transfer kepada penjual, dan pada saat penandatanganan akta jual beli, pembeli hanya menunjukkan bukti transfer sebagai bukti telah dilakukannya pembayaran kepada penjual. Maka dalam hal ini saksi akta tidak melihat sendiri secara fisik dan tidak mengetahui tentang penyerahan uang tersebut.

${ }^{8}$ GHS Lumban Tobing, Peraturan Jabatan Notaris, (Jakarta : Erlangga, 1999), hlm, 170 . 
Dengan kata lain kedudukan saksi instrumentair adalah untuk memenuhi syarat formal dari suatu akta.

Kedudukan saksi instrumentair sebagai salah satu syarat formal suatu akta Notaris disebutkan dalam Pasal 38 ayat (4) huruf c Undangundang Jabatan Notaris, bahwa pada akhir atau penutup akta harus memuat para saksi. Ketika syarat formal ini tidak terpenuhi, akta tersebut terdegradasi kedudukannya menjadi kekuatan pembuktian sebagai akta dibawah tangan. Sebagaimana yang telah diamanatkan oleh Pasal 1868 KUHPerdata dan Pasal 40 ayat (1) UUJN, akta Notaris disebut sebagai akta Notaris yang legkap apabila semua syarat formal dipenuhi, sehingga akta Notaris tersebut mempunyai kekuatan pembuktian sempurna, dan kedudukan saksi akta merupakan salah satu syarat formal dalam suatu akta Notaris dapat dipertanggungjawabkan secara hukum.

Dalam kaitannya dengan kewajiban Notaris untuk merahasiakan isi akta sebagaimana diatur dalam ketentuan Pasal 16 ayat (1) UUJN, kedudukan saksi instrumentair yang menjadi syarat sah nya suatu akta otentik bukanlah suatu pelanggaran. Kedudukan saksi instrumentair merupakan satu kesatuan dalam sebuah akta Notaris, saksi instrumentair yang berasal dari karyawan Notaris dalam praktiknya dilapangan tidaklah selalu karyawan yang mengetik akta para pihak tersebut. Tidak jarang karyawan yang menjadi saksi dalam penandatanganan dan pembacaan akta tersebut mengetahui sebatas pada saat kejadian tersebut berlangsung saja. Sehingga karyawan Notaris dalam kedudukannya sebagai saksi instrumentair tidak berkewajiban untuk mengingat isi akta tersebut.

Sepanjang saksi instrumentair tersebut tidak melakukan perbuatan melawan hukum dalam tugasnya sebagai karyawan Notaris untuk mengetik akta para pihak, maka keberadaannya dalam suatu akta Notaris tidaklah bertentangan dengan ketentuan Notaris wajib merahasiakan isi akta. Menurut penulis, saksi instrumentair secara tidak langsung juga berkewajiban untuk merahasiakan isi akta tersebut guna melindungi kepentingan dari para pihak dalam akta.

Implementasi peraturan untuk perlindungan saksi dalam memberikan perlindungan hukum kepada karyawan Notaris sebagai saksi instrumentair yang juga menjadi saksi dalam proses peradilan suatu perkara pidana adalah diatur dalam ketentuan Pasal 29 jo Pasal 30 Undang-undang Perlindungan Saksi dan Korban. Karyawan Notaris sebagai saksi dalam suatu proses perkara pidana akan mendapatkan perlindungan dari LPSK terhadap hakhaknya sebagai saksi, diantaranya adalah perlindungan terhadap hak untuk bebas dari ancaman atau tekanan pada saat memberikan kesaksian didalam pengadilan untuk suatu proses perkara pidana.Demikian pula untuk saksi perkara,baik notaris, karyawan notaris ataupun pihak lain yang terkait akta 
(Rahmida Erliyani, Muhammad Hadin Muhjad, Lia Audia Puspita)

dan dijadikan saksi dalam suatu proses pemerikaan perkara,maka keberadaan saksi saksi tersebut juga dilindungi olehh Hukum.

Apabila Notaris dijadikan saksi suatu perkara sebagai pejabat umum yang diakui kedudukan secara hukum dan dalam ketentuan peraturan hukum yang berlaku,maka notaris dalam kapasitas untuk menjaga kerahasiaan akta yang dibuatnya,maka ia juga berhak untuk menolak tidak menerangkan isi akta tersebut sepanjang demi menjaga kewajibannya merahasiakan akta dan ini merupakan hakekat dari hak ingkar notaris yang diakui oleh hukum.

Dari uraian tersebut terlihat bahwa Undang-undang Nomor 13 Tahun 2006 tentang Perlindungan Saksi dan Korban memberikan perlindungan hukum dan kepastian hukum kepada karyawan Notaris sebagai saksi dalam suatu proses peradilan perkara pidana. Kewajiban untuk merahasiakan isi akta dan keterangan yang diperoleh ini bertujuan untuk melindungi kepentingan masyarakat, khususnya para pihak yang perbuatan hukumnya dikonstantir dalam akta otentik tersebut. Berdasarkan hal tersebut maka yang berkewajiban untuk merahasiakan isi akta dan keterangan yang diperoleh dalam pembuatan akta bukan hanya Notaris saja, melainkan semua yang ada di dalam ruangan pada saat verlidjen akta, termasuk para saksi akta.

Undang-Undang secara umum mewajibkan setiap orang yang cakap untuk menjadi saksi dan memberikan kesaksian dimuka pengadilan, baik dalam proses perdata maupun proses pidana. Sebelum berlakunya UndangUndang Nomor 14 Tahun 1970 tentang Ketentuan-Ketentuan Pokok Kekuasaan Kehakiman, istilah hak ingkar merupakan terjemahan dari verschonningsrecht, akan tetapi istilah tersebut telah diberi arti lain berdasarkan Pasal 28 Undang-Undang Nomor 14 Tahun 1970 yang menyatakan sebagai berikut : "Pihak yang diadili mempunyai hak ingkar terhadap Hakim yang mengadili perkaranya."

Dalam pembuatan suatu akta Notaris, keberadaan saksi-saksi adalah mutlak. Jika suatu akta Notaris tidak melibatkan saksi-saksi maka akta tersebut adalah bukan akta otentik, melainkan suatu akta yang berkekuatan sebagai akta dibawah tangan. Notaris dalam peresmian aktanya, harus membacakan akta tersebut didepan para penghadap dan para saksi, untuk kemudian ditandatangani oleh para pihak dan para saksi tersebut. Hal ini juga dijelaskan dalam Pasal 40 UUJN bahwa setiap akta yang dibacakan oleh Notaris dihadiri paling sedikit 2 (dua) orang saksi.

Namun dengan demikian bukan berarti para saksi instrumentair tidak mengerti sama sekali terhadap isi suatu akta. Saksi instrumentair yang juga adalah karyawan Notaris jelas mengetahui formalitas yang dilakukan dalam hal pembuatan akta tersebut. Karyawan Notaris baik juga sebagai saksi instrumentair berperan sejak pengumpulan data-data pendukung dari akta 
tersebut, pembayaran segala biaya-biaya yang berhubungan dengan pembuatan akta, bahkan sampai dengan pengetikan dan penyaksian pembacaan dan penandatanganan akta, para saksi instrumentair ini sangat memahami segala sesuatu yang terdapat dalam akta itu.

Tapi hal ini tidak menyebabkan para saksi tersebut menjadi bertanggungjawab akan segala seuatu yang nantinya akan terjadi terhadap akta. Karena saksi instrumentair ini hanya menyaksikan apakah Notaris telah menjalankan syarat-syarat formalitas pembuatan suatu akta pada saat pembuatan akta tersebut. Banyak Notaris dalam praktiknya yang menjadikan karyawannya sebagai saksi instrumentair, apabila memang memenuhi persyaratan yang ditentukan oleh Undang-undang, dalam hal ini diatur dalam Pasal 40 ayat 2 UUJN.

Dalam hal melakukan pengetikan dan penyusunan rancangan akta, karyawan Notaris bertanggungjawab terhadap hasil pengetikan tersebut telah sesuai dengan rancangan. Sedangkan dalam melakukan pencocokan identitas, nama dari orang-orang yang dicantumkan dalam akta itu harus benar-benar sama dengan orang-orang yang bertindak sebagai penghadap pada pembuatan akta itu. Mereka yang nama-namanya disebut dalam akta itu harus sesuai dengan orang-orang, sebagaimana mereka itu dikenal didalam masyarakat. Oleh karena itu sebagai karyawan Notaris harus mampu mencocokkan identitas dari orang-orang yang akan disebut dalam akta sebelum pembuatan akta diresmikan, dalam hal ini pencocokan identitas tersebut menjadi tanggungjawab karyawan Notaris yang bersangkutan, namun tidak terlepas juga dari petunjuk arahan Notaris.

Pasal 1909 ayat (3) KUHPerdata menyatakan : "Semua orang yang cakap untuk menjadi saksi, diharuskan memberikan kesaksian dimuka Hakim. Namun dapatlah meminta dibebaskan dari kewajibannya memberikan kesaksian; Segala siapa yang karena kedudukannya, pekerjaannya atau jabatannya menurut Undang-Undang, diwajibkan merahasiakan sesuatu, namun hanyalah semata-mata mengenai hal- hal yang pengetahuannya dipercayakan kepadanya sebagai demikian."

Pasal 170 KUHAP memberikan kesempatan kepada Notaris untuk minta dibebaskan dari kewajiban memberikan keterangan sebagai saksi, yaitu tentang hal yang dipercayakan kepadanya. Adapun penilaian apakah alasan tersebut sah atau tidak ditentukan oleh Hakim. Apabila hakim menolak permintaan dibebaskan tersebut, maka dengan sendirinya lahirlah kewajiban bagi Notaris tersebut untuk memberikan keterangan kesaksian.

Hakim harus mempertimbangkan bahwa dalam menolak permintaan Notaris berarti hak dari Notaris tersebut telah dikurangi, dan oleh karena itu kesaksian dari Notaris hanya diminta sebagai upaya terakhir untuk melengkapi pembuktian.Kewajiban yang timbul karena permohonannya 
ditolak oleh Hakim dengan sendirinya menimbulkan konflik dengan kewajiban Notaris untuk merahasiakan isi akta.

Hak Ingkar ialah seperangkat hak terhadap yang diadili untuk mengajukan keberatan yang disertai alasan-alasan terhadap seorang Hakim yang akan mengadili perkaranya. Jadi, hak ingkar tidak lagi dihubungkan dengan hak dari seorang saksi, tetapi merupakan hak dari yang diadili dan ditujukan kepada Hakim yang akan mengadilinya. ${ }^{9}$ Istilah hak ingkar ini merupakan terjemahan dari verschonningsrecht, yang artinya adalah hak untuk dibebaskan dari memberikan keterangan sebagai saksi dalam suatu perkara perdata maupun pidana. Hak ini merupakan pengecualian dari prinsip umum bahwa setiap orang yang dipanggil sebagai saksi wajib memberikan kesaksian itu.

Hak Ingkar Notaris yang diberikan oleh Undang-Undang tidak hanya merupakan hak, akan tetapi merupakan suatu kewajiban, sehingga Notaris wajib untuk tidak bicara, sekalipun dimuka pengadilan. Meskipun Notaris oleh para kliennya diberi izin untuk bicara, masih tetap dapat mempergunakan Hak Ingkarnya, oleh karena kewajiban untuk merahasiakan bukan diletakkan keadanya oleh para klien akan tetapi oleh UndangUndang.

Dalam menentukan sampai seberapa jauh jangkauan Hak Ingkar dari para Notaris harus bertitik tolak dari kewajiban bagi para Notaris, untuk tidak bicara mengenai isi akta- aktanya, dalam arti baik mengenai yang tercantum dalam akta maupun mengenai yang diberitahukan kepadanya karena jabatannya, kecuali dalam hal-hal ada terdapat kepentingan yang lebih tinggi atau dalam hal-hal yang untuk itu Notaris oleh sesuatu peraturan perundang-undangan yang berlaku, dapat dibebaskannya secara tegas dari sumpah rahasia jabatannya.

Namun jika Notaris dipanggil menjadi saksi suatu perkara hukum terkait dengan hal tertentu dan berkaitan dengan tugas jabatannya sebagai Notaris,maka notaris dapat saja memenuhi kewajibannnya untuk menjadi saksi dalam suatu perkara sebagai bagian dari kewajibannnya sebagai warga Negara di depan hukum, namun dalam memberikan keterangan maka notaris dapat menyimpan informasi berkenaan dengan kewajibannya terkait sumpah jabatan sebatas mengenai kerahasiaan akta,namun mengenai hal lain terlepas dari kerahasian akta maka notaris bebas untuk memberikan keterangan sebagai saksi, namun mengenai isi daripada akta tersebut notaris wajib merahasiakannya karena terkait sumpah jabatannya.

${ }^{9}$ GHS Lumban Tobing. Op.Cit, hlm. 114. 


\section{Kewajiban Notaris dan Karyawan Notaris dalam menjaga kerahasian akta}

Ruang lingkup (objek) kerahasiaan jabatan Notaris dapat dilihat dalam sumpah jabatan Notaris yang diatur dalam Pasal 4 Undang-Undang Jabatan Notaris yang mengatakan bahwa Notaris bersumpah untuk merahasiakan isi akta dan keterangan yang diperoleh dalam pelaksanaan jabatan Notaris. Yang kemudian dipertegas kembali dalam Pasal 16 ayat (1) huruf (f) yang berbunyi sebagai berikut :

Dalam menjalankan jabatannya Notaris wajib merahasiakan segala sesuatu mengenai akta yang dibuatnya dan segala keterangan yang diperoleh guna pembuatan akta sesuai dengan sumpah/janji jabatan, kecuali undang-undang menentukan lain. Dan dalam penjelasa Pasal 16 tersebut diatas, kewajiban untuk merahasiakan segala sesuatu yang berhubungan dengan akta dan surat-surat lainnya adalah untuk melindungi kepentingan semua pihak yang terkait dengan akta tersebut

Siapa saja yang terikat dengan kewajiban menjaga kerahasiaan Notaris menurut Undang-Undang Jabatan Notaris Pasal 16 ayat (1) huruf (f) secara tegas ditujukan bagi Notaris, namun objek kerahasiaan jabatan Notaris tersebut tidak selalu dalam penguasaan atau kendali Notaris. Dalam hal Notaris cuti, sakit, atau berhalangan untuk menjalankan jabatannya, maka Notaris tersebut akan digantikan sementara oleh Notaris pengganti hingga berakhirnya masa cuti Notaris tersebut. Dalam hal Notaris meninggal dunia atau diberhentikan sementara dari jabatannya, maka pejabat sementara Notaris yang akan menggantikan jabatannya. UndangUndang Jabatan Notaris dalam Pasal 33 telah mengakomodasi kondisi tersebut. Dengan demikian maka dapat disimpulkan bahwa baik Notaris pengganti maupun pejabat sementara Notaris terikat dengan kewajiban menjaga kerahasiaan karena jabatannya sebagaimana halnya Notaris yang digantikannya.

Lalu bagaimana jika rahasia jabatan Notaris dibuka oleh karyawan Notaris tanpa sepengetahuan dari Notaris yang bersangkutan. Dalam hal ini Undang-Undang Jabatan Notaris tidak mengatur mengenai hal tersebut, meskipun dalam praktek banyak ditemui bahwa karyawan Notaris banyak mengetahui rahasia Notaris karena membantu pimpinannya membuat draftdraft akta, melakukan pengecekan dokumen-dokumen terkait dengan akta yang dibuat, mewakili pimpinannya bertemu dengan klien dalam batasanbatasan tertentu, dan diberikan akses penuh oleh Notaris untuk menyaksikan langsung semua aktiftas dikantor Notaris, termasuk membantu pengurusan administrasi protokol Notaris. 
Mengingat Undang-Undang Jabatan Notaris tidak mengatur kewajiban kerahasiaan terhadap karyawan Notaris, maka dalam hal terjadi pembukaan rahasia klien yang dilakukan oleh karyawannya tersebut tanpa sepengetahuan Notaris, maka akan berlaku ketentuan Pasal 1365 KUHPerdata juncto Pasal 1367 KUHPerdata, dan dengan demikian notaris wajib bertanggung jawab atas tindakan perbuatan melawan hukum yang dilakukan oleh karyawannya, dan dapat dituntut untuk membayar ganti rugi oleh pihak yag merasa hak nya merasa dirugikan karena dibukanya rahasia jabatan Notaris tersebut. Adapun Pasal 1365 dan Pasal 1367 KUHPerdata berbunyi sebagai berikut :

\section{Pasal 1365 KUHPerdata}

Tiap perbuatan yang melanggar hukum dan membawa kerugian kepada orang lain mewajibkan orang yang menimbulkan kerugian itu karena kesalahannya untuk menggantikan kerugian tersebut.

\section{Pasal 1367 KUHPerdata}

Seseorang tidak hanya bertanggung jawab, atas kerugian yang disebabkan perbuatannya sendiri, melainkan juga atas kerugian yang disebabkan perbuatan-perbuatan orang-orang yang menjadi tanggungannya atau disebabkan barang-barang yang berada dibawah pengawasannya.

Orang tua dan wali bertanggung jawab atas kerugian yang disebabkan oleh anak-anak yang belum dewasa, yang tinggal pada mereka dan terhadap siapa mereka melakukan kekuasaan orang tua atau wali.

Majikan dan orang yang mengangkat orang lain untuk mewakili urusan-urusan mereka, bertanggung jawab atas kerugian yang disebabkan oleh pelayan atau bawahan mereka dalam melakukan pekerjaan yang ditugaskan kepada orang-orang itu.

Guru sekolah atau kepala tukang bertanggung jawab atas kerugian yang disebabkan oleh murid-muridnya atau tukangtukangnya selama waktu orang-orang itu berada dibawah pengawasannya.

Tanggung jawab yang disebutkan diatas berakhir, jika orang tua, majikan,guru sekolah atau kepala tukang itu membuktikan 
bahwa mereka masing-masing tidak dapat mencegah perbuatan itu atas nama mereka seharusnya bertanggung jawab.

\section{Sanksi Berdasarkan Hukum Perdata}

Perbuatan yang bertentangan dengan prinsip kehati-hatian atau keharusan dalam pergaulan masyarakat yang baik atau yang disebut dengan istilah zorgvuldigheid juga dianggap sebagai suatu perbuatan melawan hukum. Jadi, jika seseorang melakukan tindakan yang merugikan orang lain, tidak secara melanggar pasal-pasal dari hukum yang tertulis mungkin masih dapat dijerat dengan perbuatan melawan hukum, karena tindakannya tersebut bertentangan dengan prinsip kehati-hatian atau keharusan dalam pergaulan masyarakat. Keharusan dalam pergaulan masyarakat tersebut tentunya tidak tertulis, tetapi diakui oleh masyarakat yang bersangkutan. ${ }^{10}$

Istilah perbuatan melawan hukum (onrechtmatig daad) sebelumnya diartikan secara sempit, yakni tiap perbuatan yang bertentangan dengan hak orang lain yang timbul karena Undang-Undang atau tiap perbuatan yang bertentangan dengan kewajiban hukumnya sendiri yang timbul karena undang-undang. Menurut ajaran yang sempit sama sekali tidak dapat dijadikan alasan untuk menuntut ganti kerugian karena suatu perbuatan melawan hukum, suatu perbuatan yang tidak bertentangan dengan undangundang sekalipun perbuatan tersebut

Pada awalnya hanya terdapat satu macam sanksi, yaitu sanksi kriminal berupa hukuman dalam arti sempit terkait dengan kehidupan, kesehatan, atau pemilikan. Namun kemudian juga muncul sanksi perdata bersamaan dengan perkembangan hukum perdata. Perbedaan antara hukum perdata dan hukum pidana adalah perbedaan karakter sanksinya. Sanksi dalam hukum perdata bertujuan untuk memberikan reparasi (reparation), sedangkan hukum pidana tujuannya adalah retributive atau menurut pandangan modern adalah adanya pencegahan (deterrence, prevention). ${ }^{11}$

Sanksi merupakan bagian penutup yang penting dari hukum, dan tiap aturan yang berlaku di Indonesia selalu ada sanksi pada bagian akhir hukum tersebut. Pencantuman sanksi dalam berbagai aturan hukum tersebut merupakan kewajiban yang harus dicantumkan dalam setiap aturan hukum. Ketidaktaatan atau pelanggaran terhadap suatu kewajiban yang tercantum dalam aturan hukum mengakibatkan terjadinya ketidakaturan yang sebenarnya tidak diinginkan oleh aturan hukum yang bersangkutan.Hal ini sesuai dengan fungsi hukum yang dipakai untuk penegakan hukum terhadap ketentuan-ketentuan yang biasanya berisi larangan atau yang diwajibkan.

${ }^{10}$ Ibid, hlm. 18.

11 Jimly Asshiddiqie and M. Ali Safa'at, Teori Hans Kelsen Tentang Hukum, (Jakarta : Konstitusi Press (Konpress), 2012), hlm. 46. 
Dengan demikian hakikat sanksi sebagai suatu pakasaan, juga untuk memberikan penyadaran kepada pihak yang melanggarnya, bahwa suatu tindakan yang dilakukannya tidak sesuai dengan hukum yang berlaku. ${ }^{12}$ Adanya sanksi yang diberikan kepada siapa saja yang melanggar aturan maupun norma-norma yang ada, tentu akan menjadi kontrol terhadap kemungkinan adanya benturan kepentingan antar masyarakat, sehingga suatu negara dapat berjalan lebih teratur dan harmonis.

Perbuatan mantan karyawan notaris sebagai saksi akta yang membocorkan rahasia akta dapat dikatakan perbuatan melawan hukum. Hal ini diartikan sebagai tiap perbuatan yang bertentangan dengan hak orang lain yang timbul karena undang-undang. Sifat melawan hukum secara materil berarti melanggar atau membahayakan kepentingan umum yang berhak dilindungi oleh pembuat undang-undang dalam rumusan delik tertentu. Secara formil sifat melawan hukum berarti semua bagian yang tertulis dari rumusan delik telah dipenuhi. ${ }^{13}$

Membocorkan atau membuka rahasia isi akta yang dilakukan saksi akta tersebut dapat dikategorikan sebagai suatu perbuatan melawan hukum seperti yang tercantum dalam Pasal 1365 KUH Perdata karena bertentangan dengan asas kepatutan, ketelitian, serta sikap hati-hati yang seharusnya dimiliki seseorang.

Eksistensi kewajiban hukum adalah semata-mata kepastian suatu norma hukum yang membuat sanksi tergantung kepada tindakan sebaliknya dari kewajiban hukum. Walaupun kewajiban saksi akta untuk merahasiakan isi akta tidak diatur dalam UUJN, namun ketika ia membocorkan isi akta, perbuatannya tersebut termasuk suatu perbuatan melawan hukum. Dengan demikian, berdasarkan analogi tersebut, dapat dikatakan bahwa saksi akta juga mempunyai kewajiban untuk merahasiakan isi akta dan keterangan yang diperoleh dalam pembuatan akta Notaris. Kewajiban tersebut tidak hanya berlaku ketika saksi akta dipanggil sebagai saksi dalam penyidikan atau persidangan dimuka hakim, tetapi juga diluar keadaan tersebut dan atas pelanggaran terhadap ketentuan tersebut, mantan karyawan notaris sebagai saksi akta dapat dituntut suatu ganti rugi apabila perbuatannya membocorkan rahasia akta membawa kerugian bagi pihak yang berkepentingan dengan akta tersebut.

Perbuatan itu dapat dikategorikan sebagai suatu perbuatan melawan hukum yang diatur dalam Pasal 1365 KUHPerdata, yang berbunyi :

${ }^{12}$ Habib Adjie. Op.Cit, hlm. 201.

13 E.P.H.Sutorius, Hukum Pidana. (Yogyakarta : Konsorsium Ilmu Hukum Departemen, 2004) hlm. 67. 
"Tiap perbuatan melanggar hukum, yang membawa kerugian kepada seorang lain, mewajibkan orang yang karena salahnya menerbitkan kerugian itu, mengganti kerugian."

\section{Sanksi Berdasarkan Hukum Pidana}

Jabatan Notaris merupakan jabatan kepercayaan dan untuk kepentingan masyarakat dan oleh karena itu seseorang bersedia untuk mempercayakan sesuatu kepadanya. Sebagai seseorang yang dipercaya, Notaris berkewajiban untuk merahasiakan apa saja yang diberitahukan kepadanya selama proses pembuatan akta. Oleh karena itu, memegang rahasia yang berkaitan dengan pembuatan suatu akta otentik adalah mempunyai corak hukum publik.

Undang-Undang Jabatan Notaris memang tidak mengatur kewajiban saksi akta untuk merahasiakan isi akta dan keterangan yang diperoleh dalam pembuatan akta Notaris. Namun apabila saksi akta membuka rahasia mengenai isi akta dan keterangan yang diperoleh dalam pembuatan akta Notaris, sehingga tindakan saksi akta tersebut dapat membahayakan atau merugikan pihak yang ada di dalam akta, maka dapat dikatakan bahwa saksi akta tersebut telah melakukan perbuatan melawan hukum.

Perbuatan seorang mantan karyawan Notaris sebagai saksi akta yang membuka rahasia akta bertentangan dengan kewajiban hukum si pelaku. Berbuat atau melalaikan dengan bertentangan dengan kewajiban hukum si pelaku adalah merupakan tindak-tanduk yang bertentangan dengan ketentuan undang-undang. Sesuatu perbuatan adalah melawan hukum apabila perbuatan tersebut bertentangan dengan kewajiban hukum (rectsplicht) si pelaku. Yang dimaksud dengan rechtsplicht itu sendiri adalah kewajiban yang berdasar atas hukum. Menurut pendapat umum dewasa ini, maka hukum mencakup keseluruhan norma-norma, baik tertulis maupun tidak tertulis. ${ }^{14}$

Salah satu kewajiban seorang saksi akta adalah adalah merahasiakan isi akta dan keterangan yang diperoleh dalam pembuatan akta otentik demi melindungi kepentingan masyarakat, khususnya para pihak yang terkait dengan akta tersebut sampai akhir hayat meskipun saksi akta tersebut sudah tidak lagi bekerja di kantor notaris yang bersangkutan. Berdasarkan kewajiban tersebut dapat diketahui bahwa kewajiban merahasiakan isi akta ada bukan demi kepentingan Notaris itu sendiri, melainkan demi kepentingan masyarakat yang telah memberi kepercayaan kepada Notaris. Sehingga, atas dasar hal tersebut, kewajiban untuk merahasiakan isi akta

${ }^{14}$ Ibid, hlm. 44. 
tidak hanya dimiliki oleh Notaris, namun juga semua pihak yang ada pada saat pembuatan akta otentik tersebut, termasuk saksi akta.

Sebagaimana telah disebutkan di atas bahwa kehadiran saksi akta merupakan aspek formal dalam pembuatan suatu akta otentik yang telah ditentukan oleh Undang-Undang, maka dapat saksi akta dapat disebut juga sebagai pekerjaan yang diberikan oleh Undang-Undang. Kewajiban untuk merahasiakan isi akta dan segala hal yang berkaitan dengan pembuatan akta melekat seumur hidup pada saksi akta meskipun ia sudah tidak lagi menjadi karyawan Notaris. Kewajiban untuk merahasiakan akta tersebut apabila dilanggar maka akan dapat dikenakan pidana sebagaimana yang telah disebutkan dalam Pasal 322 ayat (1) KUHP yang berbunyi :

"Barang siapa dengan sengaja membuka rahasia yang wajib disimpannya karena jabatan atau pekerjaannya, baik yang sekarang maupun yang dahulu, diancam dengan pidana penjara paling lama sembilan bulan atau pidana denda paling banyak sembilan ribu rupiah".

\section{KESIMPULAN}

Pada hakekatnya Notaris dan juga karyawan notaris yang menjadi saksi akta (saksi instrumentair) mempunyai keedudukan urgen untuk menjaga kerahasian akta sebagaimana diamanatkan oleh hukum,Kedudukan sebagai saksi terkait akta dapat berupa saksi akta dapat pula sebagai saksi perkara hukum terkait akta.

Yang berkewajiban untuk merahasiakan isi akta dan keterangan yang diperoleh dalam pembuatan akta bukan hanya Notaris saja, melainkan semua yang ada di dalam ruangan pada saat verlidjen akta, termasuk para saksi akta. Kewajiban notaris dan karyawan kantor Notaris untuk merahasiakan isi akta atau keterangan-keterangan yang diperlukan dalam pembuatan akta otentik ini melekat seumur hidup.meskipun ia telah tidak bekerja lagi dikantor notaris tersebut atau sebagai mantan karyawan Notaris.Dan kewajiban merahasikan akta oleh notaris dan karyawan notaris yang menjadi saksi akta itu merupakan kewajiban hukum yang mmepunyai implikasi hukum pula jika dilanggar.

\section{DAFTAR PUSTAKA}

\section{Buku}

E.P.H.Sutorius, Hukum Pidana. (Yogyakarta : Konsorsium Ilmu Hukum Departemen, 2004)

Habib Adjie, Penafsiran Tematik Hukum Notaris Indonesia, (Surabaya : Refika Aditama, 2017). 
Komar Sugondo, Notaris Selayang Pandang, (Bandung : Cetakan Kedua Alumni, 2000).

Lumbang Tobing, Peraturan Jabatan Notaris, (Jakarta : Erlangga, 2002).

GHS Lumban Tobing, Peraturan Jabatan Notaris, (Jakarta : Erlangga, 1999)

Salim HS, Peraturan Jabatan Notaris, (Jakarta : Sinar Grafika, 2018).

Hadin Muhjad and Nunuk Nuswardani, Penelitian Hukum Indonesia Kontemporer, (Yogyakarta: Genta Publishing, 2012).

Tan Thong Kie, Studi Notariat Dan Serba Serbi Praktek Notaris, (Jakarta : Ichtiar Baru Van Hoeve, 2000).

Jimly Asshiddiqie and M. Ali Safa'at, Teori Hans Kelsen Tentang Hukum, (Jakarta : Konstitusi Press (Konpress), 2012).

Kitab Undang-undang Hukum Perdata (Staatsblad 1847 Nomor 23);

Kitab Undang-undang Hukum Pidana;

Undang-Undang Nomor 2 Tahun 2014 terhadap Perubahan Undang-Undang Nomor 30 tahun 2004 Tentang Jabatan Notaris (Lembaran Negara Republik Tahun 2014 Nomor 3, Tambahan Lembaran Negara Republik Indonesia Nomor 5491). 